\title{
Comparison of the entrepreneurial intent of master's business students in developing countries: South Africa and Poland
}

\author{
Authors: \\ Cecile Nieuwenhuizen ${ }^{1}$ \\ Elana Swanepoel ${ }^{1}$ \\ Affiliations: \\ ${ }^{1}$ Department of Business \\ Management, University of \\ Johannesburg, South Africa

\section{Correspondence to:} \\ Cecile Nieuwenhuizen \\ Email: \\ cecilen@uj.ac.za

\section{Postal address:} \\ PO Box 524, Auckland Park \\ 2006, South Africa

\section{Dates:} \\ Received: 07 Apr. 2014 \\ Accepted: 09 Dec. 2014 \\ Published: 20 Apr. 2015 \\ How to cite this article: \\ Nieuwenhuizen, C. \& \\ Swanepoel, E., 2015, \\ 'Comparison of the \\ entrepreneurial intent of \\ master's business students \\ in developing countries: \\ South Africa and Poland', \\ Acta Commercii 15(1), Art. \\ \#270, 10 pages. http://dx.doi. \\ org/10.4102/ac.v15i1.270

\section{Copyright:} \\ (C) 2015. The Authors. \\ Licensee: AOSIS \\ OpenJournals. This work is \\ licensed under the Creative \\ Commons Attribution \\ License.
}

Problem investigated: The objective of this study was to assess the differences in the levels of entrepreneurial intent and its antecedents of the master's business students who had no exposure to entrepreneurial education from two culturally different countries, South Africa and Poland. A validated entrepreneurial intent instrument was administered to final-year master's business management students from a university in South Africa and a university in Poland.

Methodology: A cross-sectional survey design with two samples, one from each country, was used. A previously validated questionnaire developed from Ajzen's Theory of Planned Behaviour model was administered. The results were factor analysed and new scales extracted. These refined scales were used to assess the differences between the two countries. A total of 182 questionnaires were collected from the two universities, University of Johannesburg in South Africa and Krakow Business School in Poland.

Findings/implications: From the $t$-tests statistically significant differences between the two groups were found on 10 of the newly defined scales. Except on one scale, the South African students scored higher than the Polish students.

Originality/value of research: This is the first study comparing differences between master's business management students from two culturally diverse countries, South Africa and Poland, in terms of entrepreneurial intent and its antecedents.

Conclusion: Possible reasons for the differences were offered as gleaned from other research, but further research is required to identify the determining factors for the differences.

\section{Introduction and theoretical background}

Why compare entrepreneurial intent between two countries geographically far removed? What do they have in common? Prior to democratically elected governments, both South Africa (SA) and Poland experienced oppressive regimes which may have had an effect on the entrepreneurial culture in these countries. The International Monetary Fund (IMF 2013) classifies both as developing countries with low real gross domestic product (GDP) forecasts for 2014: 3.3 for SA and 2.2 for Poland. In addition, youth unemployment is high. For youths between the ages of 15 and 24, unemployment is at 31.4\% in SA (Statistics South Africa 2013) and 27.8\% in Poland (Polakowski 2012). These figures translate into a serious trepidation about employment prospects for the youth. One possible solution to the problem could be entrepreneurship, as countries with a higher increase in entrepreneurial initiative indices tend to display a decrease in unemployment levels (Audretsch 2002). Furthermore, it has been proven that entrepreneurial activity contributes to a country's long-term economic growth (Romer 1994).

Thus, an option for the youth in SA and Poland would be to pursue entrepreneurship to create their own employment and contribute to economic growth. However, the total early-stage entrepreneurial activity (TEA) rates for both these countries are low. The TEA indicates the percentage of the population aged 18 to 64 who is either a nascent entrepreneur or owner-manager of a new business. With SA at 7\% (Turton \& Herrington 2013) and Poland at 9.4\% (Tarnawa et al. 2013), both are below the average TEA rate of $13.1 \%$ for efficiency-driven economies. The Global Entrepreneurship Monitor 2012 for both SA (Turton \& Herrington 2013) and Poland (Tarnawa et al. 2013) categorises countries by geographic region and economic development level. The latter comprises three phases of economic development, namely factor-driven, efficiency-driven and innovation-driven economies. Although SA in sub-Saharan Africa and Poland in the European Union fall in different geographic regions, these two countries are both classified as having efficiency-driven economies, which are characterised by increased 
TABLE 1a: Similarities comparison of South Africa and Poland.

\begin{tabular}{|c|c|c|c|c|c|}
\hline Similarities & Real GDP 2014 Forecast - low & Youth unem-ployment: high (\%) & TEA rate: low $(\%)$ & GEM classification & IMF classification \\
\hline South Africa & 3.3 & 31.4 & 7 & $\begin{array}{l}\text { Efficiency-driven } \\
\text { economy }\end{array}$ & $\begin{array}{l}\text { Emerging and developing } \\
\text { country }\end{array}$ \\
\hline Poland & 2.2 & 27.8 & 9.4 & $\begin{array}{l}\text { Efficiency-driven } \\
\text { economy }\end{array}$ & $\begin{array}{l}\text { Emerging and developing } \\
\text { country }\end{array}$ \\
\hline
\end{tabular}

GDP, gross domestic product; TEA, total early-stage entrepreneurial activity; IMF, International Monetary Fund.

TABLE 1b: Differences comparison of South Africa and Poland.

\begin{tabular}{|c|c|c|c|c|c|}
\hline Differences & GDP per capita & Population (million) & & $\begin{array}{l}\text { Global competitiveness } \\
\text { ranking }\end{array}$ & GLOBE study classification \\
\hline South Africa & $€ 5834$ & 52.98 & - & $53 \mathrm{rd}$ & Sub-Saharan Africa \\
\hline Poland & $€ 9900$ & 39.50 & - & $42 n d$ & Eastern Europe \\
\hline
\end{tabular}

GDP, gross domestic product.

TABLE 2: Hofstede's cultural dimensions - South Africa versus Poland.

\begin{tabular}{|c|c|c|c|c|c|}
\hline Hofstede's cultural dimension & Power distance & Individuality & Masculinity & Uncertainty avoidance & Long-term orientation \\
\hline South Africa & 49 & 65 & 63 & 49 & No score \\
\hline Poland & 68 & 60 & 64 & 93 & 32 \\
\hline
\end{tabular}

industrialisation and economies of scale. The South African youth's (18-35 years of age) TEA rate is 7\% (Turton \& Herrington 2013). A youth TEA rate is not available for Poland. A summary of similarities and differences appears in Table 1a and Table1b.

However, the two countries differ in several respects. The population of SA at 52.98 million (estimate for 2013) (StatsOnline 2014:1) is about a third more than that of Poland at 39.5 million (Poland 2013:6). Consequently, the 2012 GDP per capita is higher in Poland at $€ 9900$ than in SA at $€ 5837$ (Countryeconomy 2014). With regard to competitiveness, the Global Competitiveness Report 2013-2014 (World Economic Forum 2013) ranks SA at the 53rd position and Poland with a much better ranking at the 42nd position. In addition some cultural differences exist. The GLOBE Study of 62 Societies (House et al. 2004) categorised countries into ten cultural clusters based on nine social culture practices and values. Whilst sub-Saharan Africa (including SA) scores high on only one social culture practice, namely humane orientation, and has mid-scores for the other eight practices, eastern Europe (including Poland) scores high on societal culture practices, such as assertiveness, in-group collectivism and gender egalitarianism, and low on performance orientation, future orientation and uncertainty avoidance. The two regions both have mid-scores for institutional collectivism and power distance.

According to Hofstede's classification of countries on cultural dimensions, differences exist between SA and Poland as depicted in Table 2 (The Hofstede Centre 2014a; 2014b). From the 'power distance' score it follows that both countries tend to accept a hierarchical order with inherent inequalities, both countries tend to have an individualistic society where everybody is expected to care for self and family and both countries have a masculine society where people live in order to work. However, Poland (93) scores substantially higher on uncertainty avoidance than SA (49), which means that the Polish have a very high preference for uncertainty avoidance with security being an important element in motivation, whilst SA has a low preference for uncertainty avoidance. On the dimension 'long-term orientation' Poland exhibits a tendency towards short-term orientation, which includes impatience for achieving quick results. A score for SA on this dimension is not available.

These differences in culture may have an impact on the entrepreneurial intent of the youth in these countries.

To assess whether the youth in these countries intend to start a business, entrepreneurial intent is measured as it is deemed to be the single best predictor of behaviour (Ajzen 1991) and the most powerful predictor of entrepreneurial behaviour (Autio et al. 2001). The objective of this study is, therefore, to assess whether the master's business students at the South African and Polish universities (two culturally different countries) have the intention to start a venture and to assess the differences in their level of entrepreneurial intent and its antecedents. These students were not exposed to entrepreneurial education. The contribution of the research is to assess which variables are preeminent in determining entrepreneurial intent between the two culturally diverse groups from developing countries.

\section{Theory}

To gain insight into the complex entrepreneurship process of venture creation (Gartner 1985), which involves the entrepreneur, environment and the opportunity, the cognitive factors inspiring the entrepreneur to establish a new venture are being increasingly explored (Autio et al. 2001; Forbes 1999; Krueger, Reilly \& Carsrud 2000; Liñán \& Chen 2006; Peterman \& Kennedy 2003; Tkachev \& Kolvereid 1999). Entrepreneurial cognitions are described (Mitchell et al. 2002:9) as 'the knowledge structures that people use to make assessments, judgments, or decisions involving opportunity evaluation, venture creation, and growth'. Thus, entrepreneurial intentions are defined as an individual's conscious awareness and conviction to start a new venture in the near future (Thompson 2009). 
The theory of planned behaviour (TPB) (Ajzen 1991) postulates that the greater the intention to initiate a behaviour, the higher the probability of its implementation. The TPB applied to entrepreneurial intentions of individuals hypothesises that a combination of three antecedents, personal attitudes, subjective norms and perceived behavioural control, act as initiators of the intention to create a new venture. Personal attitudes are evaluations of a specific behaviour including what individuals deem likeable, attractive or advantageous and can be both affective and evaluative (Ajzen 1991). Subjective norms denote normative beliefs and compliance thereto, as well as the perceived social pressures from significant others to perform or avoid certain behaviours (Ajzen 1991). Significant others include reference people, such as family, friends and colleagues. Perceived behavioural control refers to a person's subjective assessment of the ease or difficulty of performing a task or behaviour and the level of control over the behaviour (Ajzen 2002).

Grounded in the TBP (Ajzen 1991) and the model of entrepreneurial event (Shapero \& Sokol 1982), the ShaperoKrueger model of entrepreneurial intention was developed (Krueger et al. 2000). Likewise, Liñán, Rodríguez-Cohard and Rueda-Cantuche (2005) combined the models of Shapero and Sokol (1982) and Ajzen (2006) and the theory of social capital (Grootaert \& Van Bastelaer 2001; Uphoff 2000; Woolcock \& Narayan 2000) to create an entrepreneurial intent model with three antecedents: personal attraction towards entrepreneurship, perceived social norms and perceived feasibility (self-efficacy). Whilst Thompson (2009) was involved in the clarification of the entrepreneurial intent constructs, Liñán and Chen (2006; 2009) refined and validated the entrepreneurial intentions questionnaire (EIQ) which consisted of the following constructs: entrepreneurial intent (EI), personal attitude (PA), perceived behaviour control (PBC) and subjective norm (SN). They tested the EIQ on students from two culturally diverse samples from developed countries, namely Spain and Taiwan, and found it valid. Subsequently Liñán partnered with different authors to further test the EIQ (Liñán, Nabi \& Krueger 2013; Liñán, Rodríguez-Cohard \& Rueda-Cantuche 2011; Liñán, Urbano \& Guerrero 2011). Several other authors used different constructs to develop an EI measurement instrument (Hammami \& Affes 2013; Parente \& Feola 2013; Yang 2013). It can be concluded that a standardised EIQ does not yet exist.

The Liñán and Chen (2009) EIQ was used to test entrepreneurial intent of final year students in rural SA (Malebana 2012) and it was decided to use the same EIQ to test the entrepreneurial intent of the South African and Polish students. However, it was critical to first determine the applicability of the constructs and factors in the Liñán and Chen EIQ to the students from the two developing countries, SA and Poland. Swanepoel and Nieuwenhuizen (2014) applied factor analysis to each one of the seven construct scales to test for unidimensionality. Only two of the seven constructs were unidimensional, whilst for three constructs one or more items had to be discarded and a further two constructs subdivided into several factors. These redefined EI scales were used to differentiate between the EI of South African and Polish students and are further explained in the section on methodology.

\section{University students as a research population for entrepreneurial intent}

Using university students to test EI is appropriate as the findings can contribute to education policies and more specifically to entrepreneurship education policies and holds implications for public decision-makers who develop support programmes for entrepreneurship. Several authors have used university students to test EI (Audet 2004; Gird \& Bagraim 2008; Liñán \& Chen 2009; Liñán et al. 2013; Liñán, RodríguezCohard \& Rueda-Cantuche 2011; Liñán \& Santos 2007; Wu \& Wu 2008), specifically the effect of entrepreneurship education on EI (Malebana 2012; Peterman \& Kennedy 2003; Saeed et al. 2013; Souitaris, Zerbinati \& Al-Laham 2007).

\section{Country differences}

Whereas many researchers focus on the extent of EI in a specific group in a country, several researchers have conducted country comparisons (Table 3). The largest comparison was completed by Iakovleva, Kolvereid and Stephan (2011) who compared EI in 14 countries, whilst Engle et al. (2010) compared 12 countries and Heuer and Liñán (2013) compared 10 countries. South Africa has not been included in any of the country comparative studies whilst Poland was included in one (Moriano et al. 2012). Nevertheless, the EI of South African students has been researched by several authors (Farrington, Venter \& Neethling 2012; Gird \& Bagraim 2008; Malebana 2012; Urban 2006; 2012).

The results of a 12-country study (Engle et al. 2010) suggested that Ajzen's model of planned behaviour, as operationaliaed in that study, successfully predicts EI in each of the 12 countries. The countries included both developed and developing countries, namely Germany (Germanic Europe), France and Spain (Latin Europe), Ghana (sub-Sahara Africa), Russia (eastern Europe), Sweden and Finland (Nordic Europe), Egypt (Middle East), China (Confucian Asia), Bangladesh (southern Asia), Costa Rica (Latin America) and the United States (Anglo), with the regional cluster in parenthesis. As foreseen by Ajzen, the significant contributing model elements differed by country as did the percent of the variance explained by the model, although one model element, social norms, was a significant predictor of EI in each country.

Research into the determinants of EI of students in China and the USA revealed significant differences between the two groups pertaining to the effect of work experience and entrepreneur parents on entrepreneurial intention (Wang, Lu \& Millington 2011).

Regional differences exist not only between countries but also within a country. A study by Liñán, Urbano and 
TABLE 3: Research on entrepreneurial intent by country.

\begin{tabular}{|c|c|}
\hline Researchers (chronologically) & Countries and research participants \\
\hline Liñán, Rodríguez-Cohard \& Rueda-Cantuche 2005 & Spain - Final-year undergraduate students \\
\hline Kolvereid \& Isaksen 2006 & Norway - Business founders \\
\hline Krueger \& Kickul c. 2006 & Finland, Norway and Russia - Students \\
\hline Urban 2006 & South Africa - MBA students \\
\hline Liñán \& Santos 2007 & Spain - Final-year undergraduate students \\
\hline Gird \& Bagraim 2008 & South Africa - Final-year commerce students \\
\hline Liñán \& Chen 2009 & Spain and China - Final-year students \\
\hline Thompson 2009 & East Asia - Students from an international university \\
\hline Engle et al. 2010 & $\begin{array}{l}\text { Germany, France, Spain, Ghana, Russia, Sweden, Finland, Egypt, China, Bangladesh, Costa Rica and } \\
\text { United States - Students }\end{array}$ \\
\hline Liñán, Rodríguez-Cohard \& Rueda-Cantuche 2011 & Spain - Final-year undergraduate business students \\
\hline Liñán, Urbano \& Guerrero 2011 & Spain (two regions) - Final-year undergraduate students \\
\hline lakovleva, Kolvereid \& Stephan 2011 & $\begin{array}{l}\text { Five developing countries (Brazil, Mexico, Romania, Russia and Ukraine) - Students } \\
\text { Nine developed countries (Australia, Canada, Czech Republic, France, Germany, Norway, Spain and } \\
\text { The Netherlands) - Students }\end{array}$ \\
\hline Wang, Lu \& Millington 2011 & China and USA - College students \\
\hline Malebana 2012 & South Africa - Final-year students \\
\hline Moriano et al. 2012 & Germany, India, Iran, Poland, Spain \& The Netherlands - Students \\
\hline Farrington, Venter \& Neethling 2012 & South Africa - Students \\
\hline Urban 2012 & South Africa - MBA students \\
\hline Liñán, Nabi \& Krueger 2013 & Spain and Great Britain - Students \\
\hline Heuer \& Liñán 2013 & $\begin{array}{l}\text { Australia, Canada, Germany, the Netherlands, Norway, Mexico, Romania, Russia, Spain and Ukraine - Business } \\
\text { students enrolled in either a graduate business programme or in their last year of a bachelor programme }\end{array}$ \\
\hline Yang 2013 & China - Undergraduates \\
\hline Parente \& Feola 2013 & Italy (Campania) - PhD students \\
\hline Hammami \& Affes 2013 & Tunisia - Public civil servants \\
\hline Kautonen, Van Gelderen \& Fink 2013 & Austria and Finland - Adult population \\
\hline
\end{tabular}

Guerrero (2011) determined the environmental cognitive elements that may explain regional differences in startup intentions of potential entrepreneurs from two Spanish universities. In their study they differentiated between the valuation of entrepreneurship in a person's closer and wider environments. Items that measured the closer environment involved the valuation of entrepreneurship by direct personal contacts including family, friends and colleagues. This construct was named 'closer valuations'. The wider environment items included culture and country with the construct 'social valuation' (Liñán et al. 2011). In this study it was determined that the social valuation of entrepreneurship was higher in the more developed region of Spain with a positive effect on the perceived SNs and behavioural control of potential entrepreneurs. In the other region the 'closer valuation' was more important and it affected the attitude towards entrepreneurship and SNs of potential entrepreneurs. The conclusion was that more positive entrepreneurial values should be promoted (Liñán et al. 2011). Other studies on regional differences within a country were conducted by Kibler (2013) in Finland and Lin et al. (2013) in Shri Lanka.

A study that focused on the differences between developing and developed countries with regard to the entrepreneurial intentions of undergraduate students (Iakovleva et al. 2011) found that the TPB is fully replicable in both country groups with equal predictive power. The authors found that entrepreneurial intentions as well as attitudes, $\mathrm{SNs}$ and PBC are higher in developing countries than in developed countries. The authors suggested exploration of the robustness of the TBP on other types of students from different countries for future research. In addition they advised that it would be informative to determine how cultural antecedents and formal national institutions might influence attitudes, SNs and planned behavioural control. In compliance with these suggestions, this study will investigate the robustness of the TPB on master's in business management students from two developing countries, SA and Poland. It follows from Table 3 that no research has yet been conducted comparing these two developing countries, nor comparing SA with any other country, with regard to EI.

The research question is: Does EI and its antecedents differ between South African and Polish master's in business management students from the University of Johannesburg (UJ) and the Krakow School of Business (KSB)?

From the discussion the following propositions emerged:

- Proposition 1: A difference in the mean scores for EI exists between UJ MCom students and KSB MBA students.

- Proposition 2: A difference in the mean scores for attitude to becoming an entrepreneur (PA) exists between UJ MCom and KSB MBA students.

- Proposition 3: A difference in the mean scores for PBC exists between UJ MCom and KSB MBA students.

- Proposition 4: A difference in the mean scores for social capital exists between UJ MCom and KSB MBA students. 
- Proposition 5: A difference in the mean scores for entrepreneurial efficacy exists between UJ MCom and KSB MBA students.

- Proposition 6: A difference in the mean scores for entrepreneurial competencies exists between UJ MCom and KSB MBA students.

- Proposition 7: A difference in the mean scores for entrepreneurial support exists between UJ MCom and KSB MBA students.

\section{Methods \\ Research design}

For the cross-sectional survey design, two samples, one group from each university, were drawn from master's students in business management: MCom students at UJ, SA, and MBA students at the KSB, Poland. It should be noted that these students are not entrepreneurship students and were not subject to entrepreneurship education. In June 2013, a total of 182 questionnaires were distributed and all were completed and returned.

A comparison of the profiles of the UJ MCom and the KSB MBA students appears in Table 4. The gender distribution for the two universities was similar, approximating a 40/60 female and/or male split. The age distribution differed in the older age categories with nearly twice the number of UJ MCom students (20.5\%) in the 40-49 age bracket as opposed to KSB MBA students (11.2\%). Substantially more of the UJ MCom students (90.4\%) were employed at the time of completing the questionnaire than the KSB MBA students $(73.0 \%)$. However, nearly all of the students have been employed at some stage, UJ MCom students $96.0 \%$ and KSB MBA students $90.9 \%$.

With regard to entrepreneurial experience (Tables 4a and $4 \mathrm{~b}$ ), nearly three times more UJ MCom students (22.0\%) compared to KSB MBA students $(8.0 \%)$ were running a business. Similarly, more than three times as many UJ MCom students (47.6\%) had tried to start a business before, compared to the KSB MBA students (15.9\%). This, in spite of the fact that approximately the same percentage of KSB MBA students $(54.5 \%)$ has a family member running a business as the UJ MCom students (56.6\%). In addition, the KSB MBA students had more friends running a business $(88.6 \%$ to $72.3 \%)$ and knew more other entrepreneurs $(96.6 \%$ to $87.7 \%)$.

\section{Data collection}

The heads of the departments at UJ and KSB granted permission for the study to be conducted. The data collection took place in a classroom setting. The purpose of the study was verbally explained to the students who were informed that participation was voluntary and confidentiality and anonymity was guaranteed.

\section{Measuring instrument}

The Liñán and Chen (2009) validated EIQ adapted by Malebana (2012) was used. The latter added questions to assess the effect of university education and governmental support programmes on EI. The list of governmental support programmes was deleted from the EIQ as it did not provide meaningful information.

Section A of the EIQ collected demographic information. Section B assessed 'experience and entrepreneurial knowledge' (7 questions). Section $C$ focused on 'entrepreneurial intent' ( 9 questions), Section D on 'attitude towards becoming an entrepreneur' also known as 'personal attitude' (6 questions), Section E on 'perceived behavioural control' (9 questions), Section F on 'entrepreneurial support' (5 questions), Section G on 'social capital' (SC) (15 questions), Section $\mathrm{H}$ on 'entrepreneurial self-efficacy' (ESE) (24 questions) and Section I on 'entrepreneurial competencies' (4 questions). A nominal scale was used for questions in sections $A$ and $B$, whilst questions in sections C, D, E, F, G, H and I used a five-point Likert-type scale (for C, D, E, F \& G: 1 = strongly disagree, 5 = strongly agree; for $\mathrm{H} \& \mathrm{I}$ : 1 = very little confidence, 5 = very confident). The final instrument consisted of 82 questions.

\section{Statistical analysis}

The research analysis was completed in two phases. In phase one the applicability of the EIQ scales to samples from

TABLE 4a: Profiles - University of Johannesburg MCom students versus Krakow School of Business MBA students.

\begin{tabular}{|c|c|c|c|c|c|c|c|}
\hline \multirow[t]{2}{*}{ Demographic distribution } & \multicolumn{2}{|c|}{ Gender } & \multicolumn{3}{|c|}{ Age brackets } & \multirow[t]{2}{*}{ Currently employed (\%) } & \multirow[t]{2}{*}{ Have been employed $(\%)$} \\
\hline & Female $(\%)$ & Male (\%) & $20-29(\%)$ & $30-39(\%)$ & $40-49(\%)$ & & \\
\hline UJ MCom & 40.5 & 59.5 & 41.0 & 38.5 & 20.5 & 90.4 & 96.0 \\
\hline KSB MBA & 39.8 & 60.2 & 42.7 & 46.1 & 11.2 & 73.0 & 90.9 \\
\hline Both universities & 39.3 & 60.7 & 43.8 & 41.0 & 15.2 & 79.8 & 92.9 \\
\hline
\end{tabular}

UJ, University of Johannesburg; KSB, Krakow School of Business.

TABLE 4b: Profiles - University of Johannesburg MCom students versus Krakow School of Business MBA students.

\begin{tabular}{|c|c|c|c|c|c|c|c|}
\hline \multirow[t]{2}{*}{ Entrepeneurial experience } & \multicolumn{3}{|c|}{ Yes, currently running a business } & \multicolumn{2}{|c|}{ Know another entrepreneur } & \multicolumn{2}{|c|}{ Tried to start a business before } \\
\hline & $\operatorname{I~am~(\% )~}$ & Family member (\%) & Friends (\%) & Yes (\%) & No $(\%)$ & Yes $(\%)$ & No $(\%)$ \\
\hline UJ MCom & 22.0 & 56.6 & 72.3 & 87.8 & 12.2 & 47.6 & 52.4 \\
\hline KSB MBA & 8.0 & 54.5 & 88.6 & 96.6 & 3.4 & $15.9 \%$ & 84.1 \\
\hline Both universities & 14.2 & 54.8 & 81.4 & 92.0 & 8.0 & 31.3 & 69.7 \\
\hline
\end{tabular}

UJ, University of Johannesburg; KSB, Krakow School of Business. 
the two developing countries was assessed (Swanepoel \& Nieuwenhuizen 2014). EI (C) is the independent variable with the antecedents (D, E, F, G, H \& I) the dependent variables. For each of the seven scales (C to I) of the EIQ, the properties (construct validity and internal consistencies) were evaluated using unrestricted exploratory factor analysis (EFA), using SPSS 20 (SPSS 2012). For a detailed discussion of the seven factor analysis see Swanepoel and Nieuwenhuizen (2014). The factors that emerged were mostly different from the existing EIQ, with the exception of the first two factors, namely entrepreneurial intent and attitude to becoming an entrepreneur (personal attitude). The means instead of the interquartile range was used as the data contained few outliers (mostly fewer than four). The results appear in Table 5. The reliability was acceptable for all the factors with a Cronbach's alpha coefficient $(\alpha)$ greater than 0.7 (Nunnaly 1978) (Table 5), except G1.4.

The items relevant to each factor appear in Table 6.

Independent samples $t$-tests for equality of means were conducted on the newly created factors (included in Table 5 and Table 6 ) to assess the differences between the two independent groups, master's students from UJ and the KSB.

\section{Findings}

The number of respondents $(n)$ for the KSB group was consistent at 89 whilst it varied between 84 and 86 for the UJ group. Levene's test for equality of variances delivered a significance value larger than 0.05 for all the factors except for G1.1 and G1.2 for which the 'equal variances not assumed' option was used (Table 7). From the effect sizes, $d$, an indication of the magnitude of the differences between the two groups is evident. To interpret the $d$ value, Cohen (1988) suggests that a value of 0.2 indicates a small effect, 0.5 a medium effect and 0.8 a large effect. The results appear in Table 7.

The EI perceptions of the UJ MCom students differed significantly from the KSB MBA students on 10 of the 13 factors in Table 7.
Proposition 1: A significant difference ( $p=0.000 ; 1 \%$ level of significance) in EI (C) exists between UJ and KSB students with the UJ students showing a stronger EI.

Proposition 2: A significant difference ( $p=0.001 ; 1 \%$ level of significance) in attitude to becoming an entrepreneur (D) exists between UJ and KSB students with the UJ students showing a strongly positive attitude to becoming and entrepreneur.

Proposition 3: A significant difference ( $p=0.000 ; 1 \%$ level of significance) in PBC (E) exists between UJ and KSB students with the UJ students perceiving greater behavioural control than the KSB students.

Proposition 4: Following the EFA on social capital, four factors were extracted and the differences relating to each of these were tested. Thus proposition 4 contains four subsections. A significant difference $(p=0.016 ; 5 \%$ level of significance) existed only on the social capital factor 'knowing entrepreneurs' (G1.1) between UJ and KSB students with the KSB students knowing more entrepreneurs than the UJ students. On the other three social capital factors, namely 'valuing entrepreneurial activity' (G1.2), 'assistance from family, friends and others' (G1.3) and 'country culture support' (G1.4), the differences between the two groups were not significant. For these three factors the means of both groups ranged between 3.2 and 3.6, indicating a marginally positive perception of items comprising these factors.

Proposition 5: From the EFA on entrepreneurial self-efficacy, four factors were extracted, all showing significant differences. On factor H1.1 'managing employees' a significant difference ( $p=0.004 ; 1 \%$ level of significance) exists between UJ and KSB students with the UJ students being quite confident about their ability to manage employees. On factor H1.2 'new product development' a significant difference ( $p=0.000 ; 1 \%$ level of significance) exists between UJ and KSB students with the UJ students being more confident about their skills in new product development. On factor H1.3 'marketing and

TABLE 5: Reliability of refined factor scales (Cronbach's alpha coefficient) and summary of item analysis results pertaining to each of the 13 scales (Swanepoel \& Nieuwenhuizen 2014).

\begin{tabular}{|c|c|c|c|c|c|c|}
\hline \multicolumn{2}{|c|}{ Factor scales } & \multirow{2}{*}{$\frac{N=\text { items }}{9}$} & \multirow{2}{*}{$\frac{\text { Mean }}{31.49}$} & \multirow{2}{*}{$\begin{array}{c}\text { Variance } \\
66.10\end{array}$} & \multirow{2}{*}{$\frac{\text { Standard deviation }}{8.13}$} & \multirow{2}{*}{$\frac{\boldsymbol{\alpha}}{0.942}$} \\
\hline $\mathrm{C}$ & Entrepreneurial intent & & & & & \\
\hline D & Personal attitude & 6 & 22.68 & 26.47 & 5.14 & 0.926 \\
\hline $\mathrm{E}$ & Perceived behavioural control & 9 & 27.01 & 27.78 & 5.27 & 0.868 \\
\hline $\mathrm{F}$ & Entrepreneurial support & 4 & 11.36 & 7.54 & 2.74 & 0.748 \\
\hline G1.1 & SC: Knowing entrepreneurs & 4 & 16.42 & 9.88 & 3.14 & 0.798 \\
\hline G1.2 & SC: Valuing entrepreneurial activity & 4 & 13.72 & 8.76 & 2.96 & 0.810 \\
\hline $\mathrm{G} 1.3$ & SC: Assistance from family, friends, others & 4 & 14.42 & 8.64 & 2.94 & 0.779 \\
\hline G1.4 & SC: Country culture support & 2 & 6.48 & 2.83 & 1.68 & 0.683 \\
\hline $\mathrm{H} 1.1$ & ESE: Managing employees & 7 & 28.98 & 17.25 & 4.15 & 0.914 \\
\hline $\mathrm{H} 1.2$ & ESE: New product development & 4 & 14.82 & 8.28 & 2.88 & 0.837 \\
\hline $\mathrm{H} 1.3$ & ESE: Marketing and networking & 3 & 18.95 & 9.79 & 3.13 & 0.796 \\
\hline $\mathrm{H} 1.4$ & ESE: Financial acumen & 5 & 11.79 & 6.85 & 2.62 & 0.907 \\
\hline I & Entrepreneurial competencies & 4 & 15.60 & 7.13 & 2.67 & 0.813 \\
\hline
\end{tabular}


TABLE 6: Factors extracted from the seven scales and their items.

\begin{tabular}{ll}
\hline Item & Factors \\
\hline & Factor C: Entrepreneurial intent (EI) \\
C1 & I am ready to do anything to be an entrepreneur. \\
C2 & My professional goal is to be an entrepreneur. \\
C3 & I will make every effort to start and run my own business. \\
C4 & I am determined to create a business venture in the future. \\
C5 & I do not have doubts about ever starting my own business in the future. \\
C6 & I have very seriously thought of starting a business in the future. \\
C7 & I have a strong intention of ever starting a business in the future. \\
C8 & My qualification has contributed positively towards my interest to start a \\
& business. \\
C9 & I had a strong intention to start my own business before I started with my
\end{tabular}

Factor D: Personal attitude (PA) - Attitude to becoming an entrepreneur

D1 Being an entrepreneur implies more advantages than disadvantages to me.

D2 A career as an entrepreneur is totally attractive to me.

D3 If I had the opportunity and resources, I would like to start a business.

D4 Amongst various options, I would rather be an entrepreneur.

D5 Being an entrepreneur would give me great satisfaction.

D6 My qualification has contributed positively to my attitude towards becoming an entrepreneur.

Factor E: Perceived behavioural control (PBC)

E1 To start a business and keep it working would be easy for me.

E2 I am able to control the creation process of a new business.

E3 I believe I would be completely able to start a business.

E4 I am prepared to do anything to be an entrepreneur.

E5 I know all about the necessary practical details needed to start a business.

E6 If I wanted to, I could easily start and run a business.

E7 If I tried to start a business, I would have a high chance of being successful.

E8 It would be very easy for me to develop a business idea.

E9 My qualification has provided me with sufficient knowledge to start a business.

Factor $\mathrm{F}$ : Entrepreneurial support (ES)

F1 The government provides good support for people who want to start a business.

F2 I know the different types of support that is offered to people who want to start their own businesses.

F3 It would be easy for me to access support from government institutions.

F4 Information about government support for people who want to start their own businesses is easily accessible.

Factor G1.1: Social capital (SC) - Knowing entrepreneurs

G1 I personally know someone who is an entrepreneur in my family.

G2 I have a friend who is an entrepreneur.

G3 I personally know other people who are entrepreneurs.

G4 I personally know successful entrepreneurs in my community. Factor G1.2: Social capital (SC) - Valuing entrepreneurial activity

G7 My colleagues would approve of my decision to start a business.

G8 My immediate family values entrepreneurial activity above other activities and careers.

G9 My colleagues value entrepreneurial activity above other activities and careers.

G10 My friends value entrepreneurial activity above other activities and careers.

Factor G1.3: Social capital (SC) - Assistance from family, friends, others

G5 My immediate family would approve of my decision to start a business.

G13 I can rely on my family for assistance in starting a business.

G14 I can rely on my friends for assistance in starting a business.

G15 I can rely on other entrepreneurs for assistance in starting a business.
TABLE 6 (Continues...): Factors extracted from the seven scales and their items.

Item Factors

Factor G1.4: Social capital (SC) - Country culture support

G11 The culture in my country is highly favourable towards entrepreneurial activity.

G12 In my country, entrepreneurial activity is considered worthwhile, despite the risks.

Factor H1.1: Entrepreneurial self-efficacy - Managing employees

H14 Recruit and train new employees.

H15 Delegate tasks and responsibilities to employees in my business.

H16 Supervise employees.

H17 Deal effectively with day-to-day problems and crises.

H18 Inspire, encourage and motivate my employees.

H19 Develop a working environment that encourages people to try out new things.

H2O Persist in the face of adversity.

Factor H1.2: Entrepreneurial self-efficacy - New product development

H1 Generate a new idea for a product or service.

H2 Identify the need for a new product or service.

H3 Design a product or service that will satisfy customer needs and wants.

H4 Estimate customer demand for a new product or service.

Factor H1.3: Entrepreneurial self-efficacy - Financial acumen

$\mathrm{H} 22$ Organise and maintain the financial records of my business.

H23 Manage financial assets of my business.

H24 Read and interpret financial statements.

Factor H1.4: Entrepreneurial self-efficacy - Marketing and networking

H5 Determine a competitive price for a new product or service.

H7 Design an effective marketing or advertising campaign for a new product or service.

H8 Get others to identify with and believe in my vision and plans for a new business.

H9 Make contact with and exchange information with others.

H12 Develop and maintain favourable relationships with potential investors. Factor I: Entrepreneurial competencies (EC)

I1 The ability to recognise and evaluate opportunities in the market.

12 The ability to develop relationships with other business people for mutual learning and collaborative working to achieve common objectives.

13 The ability to persuade and discuss with various stakeholders about the issues that involve the business.

4 The ability to make sacrifices to ensure that the business gets started.

networking' a significant difference ( $p=0.001 ; 1 \%$ level of significance) exists between UJ and KSB students with the UJ students being more and fairly confident about their marketing and networking proficiencies. On factor H1.4 'financial acumen' a significant difference ( $p=0.000 ; 1 \%$ level of significance) exists between UJ and KSB students with the UJ students being more confident.

Proposition 6: A significant difference ( $p=0.000 ; 1 \%$ level of significance) in the perception of their entrepreneurial competencies (factor I) exists between UJ and KSB students with the UJ students being more confident about their entrepreneurial competencies than the KSB students.

Proposition 7: A significant difference ( $p=0.039 ; 5 \%$ level of significance) in entrepreneurial support exists between UJ and KSB students with both groups having a negative view but the KSB students being more negative about entrepreneurial support. 
TABLE 7: $t$-test for differences between University of Johannesburg and Krakow School of Business master's students and effect sizes.

\begin{tabular}{|c|c|c|c|c|c|c|c|c|}
\hline \multirow{2}{*}{$\begin{array}{l}\text { Newly created } \\
\text { factors }\end{array}$} & \multirow[t]{2}{*}{ Levene's test ${ }^{\mathrm{a}, \mathrm{b}}$} & \multicolumn{2}{|c|}{ Mean } & \multicolumn{3}{|c|}{$t$-test for equality of means } & \multirow[t]{2}{*}{ Effect size $d$} & \multirow[t]{2}{*}{ Effect } \\
\hline & & UJ & KSB & $t$ & Df & Sig. (2-tailed) & & \\
\hline C & eva & 3.88 & 3.15 & -5.834 & 173 & $0.000 * *$ & 0.887 & Large \\
\hline E & eva & 3.59 & 3.16 & -4.420 & 172 & $0.000 * *$ & 0.674 & Large \\
\hline G1.1 & eva-not & 3.98 & 4.27 & 2.427 & 164.219 & $0.016^{*}$ & 0.372 & Medium \\
\hline G1.2 & eva-not & 3.48 & 3.37 & -0.945 & 170.632 & 0.346 & 0.144 & Small \\
\hline G1.3 & eva & 3.62 & 3.62 & 0.003 & 172 & 0.998 & 0.001 & Small \\
\hline G1.4 & eva & 3.29 & 3.21 & -0.585 & 172 & 0.559 & 0.089 & Small \\
\hline H1.1 & eva & 4.25 & 3.97 & -2.919 & 171 & $0.004 * *$ & 0.447 & Medium \\
\hline $\mathrm{H} 1.2$ & eva & 3.91 & 3.48 & -4.009 & 171 & $0.000 * *$ & 0.613 & Large \\
\hline $\mathrm{H} 1.3$ & eva & 4.15 & 3.70 & -3.458 & 171 & $0.001 * *$ & 0.486 & Medium \\
\hline $\mathrm{H} 1.4$ & eva & 3.99 & 3.58 & -4.588 & 171 & $0.000 * *$ & 0.702 & Large \\
\hline $\mathrm{F}$ & eva & 2.96 & 2.74 & -2.077 & 172 & $0.039 *$ & 0.317 & Medium \\
\hline
\end{tabular}

\section{Conclusion and implications}

Whereas, significant statistical differences between the SA and Polish students were evident from the t-test, the effect sizes, indicating practical significance, varied. UJ MCom students scored higher and differed largely from KSB MBA students on 6 of the 10 factors on which they differed significantly, namely EI, attitude towards becoming an entrepreneur, $\mathrm{PBC}$, new product development, financial acumen and entrepreneurial support. The KSB students indicated that they know more entrepreneurs than the UJ students but the effect size is medium. The UJ students scored higher on managing employees and marketing and networking than the KSB students, but with a medium effect size. The same applied to entrepreneurial competencies. It is possible that the lower EI of the Polish students can be linked to the country's cultural orientation, scoring low on performance orientation, future orientation and uncertainty avoidance (House et al. 2004), constructs that are implicit in entrepreneurial self-efficacy and perceived behaviourial control. Confirming that the TPB is fully replicable in both developing and developed countries, Iakovleva et al. (2011) found that the TPB had a marginally higher predictive power for developing as opposed to developed countries. With regard to developing countries Iakovleva et al. suggested that 'excessively stable or socialistic social systems might be a natural barrier to developing entrepreneurial intent of a country' (p. 365). Emerging from a socialist social system, the Polish students' lower scores on the EI constructs could be partly contributed to their history.

Only one other TPB study has included Poland in a sixcountry cross-cultural study (Moriano et al. 2012), classifying Poland as exhibiting rather high in-group collectivism practices, according to the GLOBE study (House et al. 2004), as opposed to an individualistic country. The findings did not support the proposition that SNs have stronger effects on entrepreneurial intentions in collectivistic countries (India, Iran, Spain and Poland).

From a 10-country study (see Table 3), Heuer and Liñán (2013) concluded that the results regarding socioeconomic variables seem to confirm those of previous studies. The authors referred to the research by Van Stel et al. (2003) who postulated that individuals in high-income countries should score lower on start-up intention as a result of lower necessity motivations. As Poland has a higher per-capita income than South Africa, it is thus expected that the Polish students would score lower on EI than South African students.

In a review of culture and EI, Hayton and Cacciotti (2014:159) concluded that 'rather than convergence the growth in literature on relationship between national cultural dimensions and entrepreneurial activity is diverging in its evidence base'. Further research is required to explain the differences between South African and Polish master's students with regard to EI. Further calculations will be undertaken in the next phase of this project to determine the relationship between the 13 independent variables by means of structural equation modelling.

The research contributes to the body of knowledge on cultural differences in EI of business management students who were not exposed to entrepreneurial education.

\section{Acknowledgements}

Our sincere gratitude is extended to the Krakow Business School, Poland, for allowing their MBA students to complete the questionnaire and for their assistance with the process of questionnaire completion.

\section{Competing interests}

The authors declare that they have no financial or personal relationship(s) that may have inappropriately influenced them in writing this article. 


\section{Authors' contributions}

C.N. (University of Johannesburg) was the project leader and E.S. (University of Johannesburg) wrote the manuscript.

\section{References}

Ajzen, I., 1991, 'The theory of planned behaviour', Organisational Behaviour and Human Decision Processes 50(2), 179-211. http://dx.doi.org/10.1016/07495978(91)90020-T

Ajzen, I., 2002, 'Perceived behavioural control, self-efficacy, locus of control, and the Theory of Planned Behaviour', Journal of Applied Social Psychology 32(4), 665683. http://dx.doi.org/10.1111/j.1559-1816.2002.tb00236.x

Ajzen, I., 2006, Constructing a TpB questionnaire: Conceptual and methodological considerations, viewed 25 June 2008, from http://www-unix.oit.umass. edu a aizen/pdf/tpb.measurement

Audet, J., 2004, A longitudinal study of the entrepreneurial intentions of university students, viewed 03 November 2007, from http://www.fsa.ulaval.ca/cepme/ Articles\&documents/Allied 2004.pdf

Audretsch, D.B., 2002, Entrepreneurship: Determinants and policy in a European-US comparison, Kluwer Academic, Boston, MA. http://dx.doi.org/10.1007/b109395

Autio, E., Keeley, R.H., Klofsten, M., Parker, G.G.C. \& Hay, M., 2001, 'Entrepreneurial Intent among Students in Scandinavia and in the USA',
Enterprise and Innovation Management Studies 2(2), 145-160. http://dx.doi. org/10.1080/14632440110094632

Cohen, J.W., 1988, Statistical power analysis for the behavioral sciences, 2nd edn. Lawrence Erlbaum Associates, Hillsdale, NJ.

Countryeconomy, 2014, Countries comparison, viewed 19 January 2014, from http:// www.countryeconomy.com/ countries/compare/poland/southafrica

Engle, R., Dimitriade, N., Gavidia, J., Schlaegel, C., Delanoe, S., Alvarado, I. et al., 2010, 'Entrepreneurial intent: A twelve-country evaluation of Ajzen's model of planned
behaviour', International Journal of Entrepreneurial Behaviour and Research behaviour', International Journal of Entrepreneurial Behaviour
16(1), 35-57. http://dx.doi.org/10.1108/13552551011020063

Farrington, S.M., Venter, D.J.L. \& Neethling, A., 2012, 'Perceptions of South African business science students', Management Dynamics 21(3), 17-32.

Forbes, D.P., 1999, 'Cognitive approaches to new venture creation', International Journal of Management Reviews 1(4), 415-439. http://dx.doi.org/10.1111/14682370.00021

Gartner, W.B., 1985, 'A conceptual framework for describing the phenomenon of new venture creation', Academy of Management Review 10(4), 696-706.

Gird, A. \& Bagraim, J.J., 2008, 'The theory of planned behaviour as predictor of entrepreneurial intent amongst final year university students', South African Journal of Psychology 38(4), 711-724. http://dx.doi. org/10.1177/008124630803800410

Grootaert, C. \& Van Bastelaer, T., 2001, Understanding and measuring social capital: A synthesis of findings and recommendations from the social capital initiative'working paper no. 24, Social Capital Initiative, The World Bank, Washington, DC

Hammami, H. \& Affes, H., 2013, 'The entrepreneurial intention between reasoned action and planned behavior: Empirical evidence in the case of the Tunisian public civil servants', Advance in Management 6(6), 28-33.

Hayton, J. \& Cacciotti, G., 2014, 'Culture and entrepreneurship: Empirical evidence for direct and indirect effects', in A. Fayolle (ed.), A Handbook of research on entrepreneurship: What we know and what we need to know, pp. 1417-183, Edward Elgar, Cheltenham. http://dx.doi org/10.4337/9780857936929.00014

Heuer, A. \& Liñán, F., 2013, 'Testing alternative measures of subjective norms in entrepreneurial intention models', International Journal of Entrepreneurship and Small Business 19(1), 35-50. http://dx.doi.org/10.1504/IJESB.2013.054310

House, R.J., Hanges, P.J., Javidan, M., Dorfman, P.W. \& Gupta, V. (eds.), 2004, Culture, leadership, and organizations: The GLOBE study of 62 societies, Sage, London.

lakovleva, T., Kolvereid, L. \& Stephan, U., 2011, 'Entrepreneurial intentions in developing and developed countries', Education and Training 53(5), 353-370. http://dx.doi.org/10.1108/00400911111147686

International Monetary Fund, 2013, World Economic Outlook April 2013 - Hopes, Realities, Risks, IMF, Washington, DC.

Kautonen, T., Van Gelderen, M. \& Fink, M., 2013, 'Robustness of the theory of planned behavior in predicting entrepreneurial intentions and actions', Entrepreneurship Theory and Practice (July), 1-20.

Kibler, E., 2013, 'Formation of entrepreneurial intentions in a regional context', Entrepreneurship \& Regional Development: An International Journal 25(3-4), 293-323. http://dx.doi.org/10.1080/08985626.2012.721008

Kolvereid, L. \& Isaksen, E., 2006, 'New business start-up and subsequent entry into self-employment', Journal of Business Venturing 21, 866-885. http://dx.doi org/10.1016/j.jbusvent.2005.06.008

Krueger, N.F., Reilly, M.D. \& Carsrud, A.L., 2000, 'Competing models of entrepreneuria intentions', Journal of Business Venturing 15(5-6), 411-432. http://dx.doi. org/10.1016/S0883-9026(98)00033-0

Kruger, N.F. \& Kickul, J., 2006, So you thought the intentions model was simple? Cognitive style and the specification of entrepreneurial intentions models, viewed 20 January 2014, from http://ssrn.com/abstract=1150881
Lin, X., Carsrud, A., Jagoda, K. \& Shen, W., 2013, 'Determinants of entrepreneurial intentions: Applying a western model to the Sri Lanka context', Journal of intentions: Applying a western model to the Sri Lanka context', Journal of
Enterprising Culture 21(02), 153. http://dx.doi.org/10.1142/S0218495813500076

Liñán, F. \& Chen, Y., 2006, Testing the entrepreneurial intention model on a twocountry sample, viewed 28 August 2007, from http://www.recercat.net/ bitstream/2072/2213/1/UABDT06-7.pdf

Liñan, F. \& Chen, Y.W., 2009, 'Development and cross-cultural application of a specific instrument to measure entrepreneurial intentions', Entrepreneurship Theory and Practice 33(3), 593-617. http://dx.doi.org/10.1111/j.1540-6520.2009.00318.x

Liñán, F., Nabi, G. \& Krueger, N., 2013, 'British and Spanish entrepreneurial intentions: A company study', Revista de Economia Mundial 33, 73-103.

Liñán, F., Rodríguez-Cohard, J.C., \& Rueda-Cantuche, J.M., 2005, 'Factors affecting entrepreneurial intentions', paper presented at the 45th Congress of European Regional Science Association, Amsterdam, the Netherlands, 23-25 August 2005.

Liñán, F., Rodríguez-Cohard, J.C. \& Rueda-Cantuche, J.M., 2011, 'Factors affecting entrepreneurial levels: A role for education', International Entrepreneurship Management Journal 7, 195-218. http://dx.doi.org/10.1007/s11365-010-0154-z

Liñán, F. \& Santos, F.J., 2007, 'Does social capital affect entrepreneurial intentions?' International Advanced Economic Research 13, 443-453. http://dx.doi. org/10.1007/s11294-007-9109-8

Liñán, F., Urbano, D. \& Guerrero, M., 2011, 'Regional variations in entrepreneurial cognitions: Start-up intentions of university students in Spain', Entrepreneurship \& Regional Development 23(3-4), 187-215.

Malebana, M.J., 2012, 'Entrepreneurial intent of final-year commerce students in the rural provinces of South Africa', doctoral thesis, Department of Business Management, University of South Africa.

Mitchell, R.K., Smith, J.B, Morse, E.A., Seawright, K.W., Peredo, A.M. \& McKenzie B., 2002, 'Are entrepreneurial cognitions universal? Assessing entrepreneuria cognitions across cultures', Entrepreneurship: Theory and Practice 26(4), 9-32.

Moriano, J.A., Gorgievski, M., Laguna, M., Stephan, U. \& Zarafshani, K., 2012, 'A crosscultural approach to understanding entrepreneurial intention', Journal of Caree Development 39(2), 162-185. http://dx.doi.org/10.1177/0894845310384481

Nunnally, J.O., 1978, Psychometric theory, McGraw-Hill, New York, NY.

Parente, R. \& Feola, R., 2013, 'Entrepreneurial intent and entrepreneurial commitment of young researchers', International Journal of Technology Management \& Sustainable Development 12(2), 155-166. http://dx.doi.org/10.1386/tmsd.12.2.155_1

Peterman, N.E. \& Kennedy, J., 2003, 'Enterprise education: Influencing students' perceptions of entrepreneurship', Entrepreneurship Theory \& Practice (Winter) 129-144. http://dx.doi.org/10.1046/j.1540-6520.2003.00035.x

Polakowski, M., 2012, Youth unemployment in Poland, Friedrich Ebert Stiftung, Berlin. Poland, 2013, Poland quarterly statistics, viewed 15 January 2014, from http://www. stat.gov.pl/gus/5840_2776_ENG

Romer, P., 1994, 'The origins of endogenous growth', Journal of Economic Perspectives 8(1), 3-22. http://dx.doi.org/10.1257/jep.8.1.3

Saeed, S., Yousafzai, S.Y., Yani-De-Soriano, M. \& Muffatto, M., 2013, 'The role of perceived university support in the formation of students' entrepreneurial intention', Journal of Small Business Management 29(Dec), 1-20.

Shapero, A. \& Sokol, L., 1982, 'The social dimension of entrepreneurship', in C.A. Kent, D.L. Sexton \& K.H. Vester (eds.), The Encyclopedia of Entrepreneurship, pp. 72-90, Prentice-Hall, Englewood Cliffs, NJ.

Souitaris, V., Zerbinati, S. \& Al-Laham, A., 2007, 'Do entrepreneurship programmes raise entrepreneurial intention of science and engineering students? The effect of learning, inspiration and resources', Journal of Business Venturing 22(4), 566-591. $\mathrm{http}: / /$ dx.doi.org/10.1016/j.jbusvent.2006.05.002

StatsOnline, 2014, Latest key indicators, viewed 15 January 2014, from http://www. statssa.gov.za/keyomdocators/

Statistics South Africa, 2013, Quarterly labour force survey, Quarter 3, 2013. Statistical release P0211, viewed 11 November 2013, from http://www.statssa.gov.za

Swanepoel, E. \& Nieuwenhuizen, C., 2014, 'Applicability/validation of the factors of the entrepreneurial intent questionnaire in developing countries: South Africa and Poland', in press (available from the authors).

Tarnawa, A., Węcławska, D., Zbierowski, P. \& Bratnicki, M., 2013, Globa Entrepreneurship Monitor Report - Poland 2012, Polska Agencja Rozwoju Przedsiębiorczości, Warsaw.

The Hofstede Centre, 2014a, Poland, viewed 15 January 2014, from http://www. geert-hofstede.com/poland.html

The Hofstede Centre, 2014b, South Africa, viewed 15 January 2014, from: http://www.geert-hofstede.com/south-africa.html

Thompson, E.R., 2009, 'Individual entrepreneurial intent: Construct clarification and development of an internationally reliable metric', Entrepreneurship Theory and Practice 33(3), 669-694. http://dx.doi.org/10.1111/j.1540-6520.2009.00321.x

Tkachev, A. \& Kolvereid, L., 1999, 'Self-employment Intentions among Russian students', Entrepreneurship and Regional Development 11(3), 269-280. $\mathrm{http}: / / d x$.doi.org/10.1080/089856299283209

Turton, N. \& Herrington, M., 2013, Global entrepreneurship monitor 2012 South Africa, Graduate School of Business, University of Cape Town, Cape Town.

Uphoff, N., 2000, 'Understanding social capital: Learning from the analysis and experience of participation', in P. Dasgupta \& I. Serageldin (eds.), Social capital, a multifaceted perspective, pp. 215-249, The World Bank, Washington, DC.

Urban, B., 2006, Entrepreneurship in the rainbow nation: Effect of cultural values and ESE on intentions, Journal of Developmental Entrepreneurship11(3), 171-186. http://dx.doi.org/10.1142/S1084946706000386 
Urban, B., 2012, 'A metacognitive approach to explaining entrepreneurial intentions', Management Dynamics 21(2), 16-33.

Urban, B., 2012, 'Applying a metacognitive perspective to entrepreneurship: Empirical evidence on the influence of metacognitive dimensions on entrepreneurial intentions', Journal of Enterprising Culture 20(2), 203-225. http://dx.doi. org/10.1142/S0218495812500094

Van Stel, A., Wennekers, S., Turik, R., Reynolds, P.D. \& De Wit, G., 2003, 'Explaining nascent entrepreneurship across countries', SCALES paper N200301, viewed 12 December 2009, from http://repub.eur.nl/res/pub/9819

Wang, W., Lu, W. \& Millington, J.K., 2011, 'Determinants of entrepreneurial intention among college students in China and USA', Journal of Global Entrepreneurship Research 1(1), 35-44.
Woolcock, M. \& Narayan, D., 2000, 'Social capital: Implications for development theory, research and policy', The World Bank Research Observer 15(2), 225-249. http://dx.doi.org/10.1093/wbro/15.2.225

World Economic Forum, 2013, The global competitiveness report 2013-2014 viewed 26 November 2013, from http://www.weforum.org/reports/globalcompetitiveness-report-2013-2014

Wu, S. \& Wu, L., 2008, 'The impact of higher education on entrepreneurial intentions of university students in China', Journal of Small Business and Enterprise Development 15(4), 752-774. http://dx.doi.org/10.1108/14626000810917843

Yang, J., 2013, 'The theory of planned behaviour and prediction of entrepreneurial intention among Chinese undergraduates', Social Behavior and Personality 41(3), 367-376. http://dx.doi.org/10.2224/sbp.2013.41.3.367 